\title{
CONTRIBUȚII ALE EDUCAȚIEI FIZICE ȘI SPORTULUI LA ÎNDEPLINIREA OBIECTIVELOR AGENDEI 2030 A ONU PENTRU DEZVOLTARE DURABILĂ
}

\author{
CONTRIBUTIONS OF PHYSICAL EDUCATION AND SPORT \\ TO THE ACHIEVEMENT OF THE UN 2030 AGENDA \\ SUSTAINABLE DEVELOPMENT
}

\author{
CONTRIBUTIONS DE L'ÉDUCATION PHYSIQUE ET DU SPORT \\ À LA RÉALISATION DE L'AGENDA 2030 DES NATIONS UNIES \\ POUR LE DÉVELOPPEMENT DURABLE
}

Lt.col.instr.sup.drd. Marius Constantin ISTRATE*

\begin{abstract}
Articolul prezintă, într-o manieră succintă, cele 17 obiective prioritare ale Organizației Națiunilor Unite privitoare la dezvoltarea durabilă, cuprinse în Agenda 2030. Aceste obiective se referă la conservarea planetei, la grija față de ecosistemele acesteia și la creșterea calitătiii vieții locuitorilor de pe întreg mapamondul. Pe lângă abordarea sistematizată a obiectivelor Agendei 2030, articolul reliefează legătura educației fizice și sportului cu posibilitățile de dezvoltare ale societății din alte domenii, astfel încât teoria să se poată materializa în practică. Prezentarea lor în paralel, în acest format este o motivație suficient de puternică, pentru a atrage atenția asupra domeniului de interes și pentru a-l înțelege mult mai profund, și demonstrează că educația fizică și sportul reprezintă un sistem complex de valori, mijloace specifice și valențe, care, puse în valoare în mod corespunzător și utilizate într-un mod ingenios, devin căi viabile în realizarea celor 17 obiective de dezvoltare durabilă.
\end{abstract}

The article summarizes the 17 priority goals of the United Nations on sustainable development in the 2030 Agenda. These goals are to save the planet, care for its ecosystems and increase the quality of life of people around the world. In addition to the systematic approach to the objectives of the 2030 Agenda, the article highlights the link between physical education and sport and the development possibilities of society in other fields, so that the theory can materialize in practice. Their parallel presentation, in this format, is a strong enough motivation to draw attention to the field of interest and understand it much more deeply and demonstrates that physical education and sport represent a complex system with values, specific means and valences, which, properly valued and used in an ingenious way become viable ways to achieve the 17 goals of sustainable development.

L'article expose de manière concise les 17 objectifs prioritaires des Nations Unies pour le développement durable, définis dans l'Agenda 2030. Ces objectifs concernent la préservation de la planète, le soin de ses écosystèmes et l'amélioration de la qualité de vie des populations du monde entier. Outre l'approche systématique des objectifs de l'Agenda 2030, l'article met en évidence le rapport entre l'éducation physique et le sport et les opportunités de développement de la société dans d'autres domaines, de sorte que la théorie peut être mise en pratique. Leur présentation en parallèle, dans ce format, est une motivation assez forte pour susciter l'intérêt sur ce domaine important et pour le comprendre beaucoup plus profondément, et démontre que l'éducation physique et le sport sont un système complexe de valeurs, de moyens spécifiques et de capacités, qui, correctement valorisés et utilisés de façon intelligente, deviennent des moyens viables pour atteindre les 17 objectifs de développement durable.

Cuvinte-cheie: educație fizică; sport; dezvoltare durabilă; obiective.

Keywords: physical education; sports; sustainable development; objectives.

Mots-clés: éducation physique; sport; développement durable; objectifs.

*Universitatea Națională de Apărare „Carol I”

e-mail: mariusconstantinistrate@yahoo.com 
Organizația Naţiunilor Unite reprezintă cea mai importantă organizație la nivel global, ale cărei misiuni prioritare sunt: asigurarea păcii la nivel mondial; cooperarea internațională dintre statele lumii; medierea eventualelor conflicte care apar între acestea; garantarea și respectarea drepturilor și libertăților fundamentale ale omului, precum și dezvoltarea durabilă, concept care se referă la existența unei medieri permanente între progresul economic și cel social, protejând, în același timp, echilibrul natural al Pământului.

Educația fizică și sportul, valențele și mijloacele proprii acestor activități, utilizate într-un mod inteligent și interesant, pot deveni pârghii sustenabile care servesc dezvoltarea durabilă, reușind în acest fel să ajute la îndeplinirea fiecărui obiectiv cuprins în actuala strategie a Organizației Naţiunilor Unite. Astfel, obiectivele prezentului articol pleacă de la necesitatea cunoașterii posibilei implicări a educației fizice și sportului în toate celelalte ramuri sociale, înțelegerii acestui domeniu ca vector sau liant între toate domeniile care favorizează evoluția socială, precum și aprofundării obiectivelor Agendei 2030, ca puncte de reper pentru managementul de viitor al educației fizice și sportului.

\section{Dimensiunile dezvoltării durabile, piloni de bază ai garantării unei vieți de calitate pentru toți locuitorii planetei}

Dezvoltarea durabilă reprezintă ,dezvoltarea care urmărește satisfacerea nevoilor prezentului, fără a compromite posibilitatea generațiilor viitoare de a-şi satisface propriile nevoi"’.

Plecând de la ideea de bază a acestui concept, și anume garantarea unei vieți de calitate pentru toți locuitorii planetei atât în prezent, cât și în viitor, ONU se preocupă permanent de identificarea de soluții și de luarea de măsuri care să ghideze evoluția societăţii umane, progresul economic și social în viitor, de generarea unor seturi de valori care privesc omul, individul, necesitățile sale actuale și ale generaţiilor următoare, asociat $\mathrm{cu}$ protejarea mediului natural și conservarea ecosistemelor planetei noastre.

În acest sens, în data de 25 septembrie 2015, în cadrul Summitului special ONU, desfășurat la New York, s-a adoptat, prin Rezoluția A/RES/70/1, „Agenda 2030 pentru Dezvoltare Durabilă Transformarea lumii noastre", care urmărește îndeplinirea a 17 obiective (ODD), privitoare la dezvoltarea durabilă, a 169 de ținte complementare acestora, obiective cu un caracter general și universal şi, de asemenea, echilibrul dintre cele trei dimensiuni definitorii care privesc dezvoltarea durabilă: dimensiunea socială, dimensiunea economică şi dimensiunea de mediu. Cei trei piloni care stau la baza Agendei 2030 pentru Dezvoltare Durabilă au fost definiți, încă din anul 1987, în Raportul Comisiei Brundtland²:

Dimensiunea socială (de echitate socială) asigură nevoile de bază privind calitatea vieții ca: ocuparea forței de muncă prin crearea de noi locuri de muncă, alimentație, asigurarea utilităților (apă, energie, canal) și în țările sub și mediu dezvoltate.

Dimensiunea economică (de creștere economică) este necesară națiunilor în curs de dezvoltare, pentru reducerea decalajelor privind calitatea vieții, comparativ cu țările dezvoltate.

Dimensiunea de mediu (de protecție și de conservare a mediului inconjurător) are în vedere schimbarea treptată a modului de dezvoltare și folosirea unor tehnologii noi, ecologice, care să protejeze și să conserve mediul înconjurător și care să îmbunătățească baza de resurse naturale disponibile. Documentul are implicații directe în politicile interne și externe ale statelor lumii, şi pentru îndeplinirea acestui proiect deosebit de ambiţios, sunt mobilizate toate țările și părțile interesate. În această rezoluție, la punctul 37 se stipulează că ,activitățile fizice şi sportive sunt un factor important de dezvoltare durabilă. Recunoaștem contribuția crescândă a acestora la realizarea dezvoltării și păcii, în promovarea toleranței şi respectului și contribuţia pe care acestea o exercită la împuternicirea femeilor și a tinerilor în cadrul comunităților, precum și pentru îndeplinirea obiectivelor privind sănătatea, educația și incluziunea socială”’3.

\section{Educația fizică și sportul, vectori cu potențial major de dezvoltare durabilă}

În viziunea ONU, educația fizică și sportul sunt activităţi cu potențial deosebit în dezvoltarea durabilă, acestea putând fi implicate constructiv în îndeplinirea tuturor obiectivelor (17 obiective) din Agenda 2030 a $\mathrm{ONU}^{4}$ : eradicarea sărăciei; eradicarea foametei; sănătate şi bunăstare; educaţie de calitate; egalitate între sexe; apă curată şi sanitație; energie curată şi la prețuri accesibile; 
muncă decentă şi creştere economică; industrie, inovație şi infrastructură; inegalități reduse; oraşe şi comunităţi durabile; consum şi producție responsabile; acțiuni de stabilizare climatică; viața acvatică; viaţa terestră; pace, justiție şi instituții eficiente; parteneriate pentru realizarea obiectivelor.

În această prezentare, obiective ale Agendei 2030 - educație fizică și sport, am indicat în paralel, în sinteză, ca urmare a studiului principalelor resurse bibliografice de actualitate, viziunea personală privind șansele integrării și mai aprofundate a educației fizice și sportului în toate domeniile sociale.

Eradicarea sărăciei, în orice context, formă şi zonă geografică, este un obiectiv care vizează scăderea drastică a numărului oamenilor care trăiesc în sărăcie extremă, stimularea cooptării celor apți de muncă pe piața muncii, dezvoltarea unui sistem de protecție și asistență socială. Educația fizică și sportul, prin abilitățile și valențele specifice, pot avea un rol important în eradicarea sărăciei și în crearea unei vieți durabile și prospere pe termen lung. Astfel, o parte dintre veniturile obţinute prin acțiuni specifice (meciuri demonstrative, competiții sportive, licitații cu obiecte ale unor personalităţi din domeniu), din publicitate și din alte activități generatoare de fonduri poate fi folosită în cadrul unor programe și parteneriate pentru atingerea acestui scop nobil.

Eradicarea fenomenului foametei este un obiectiv care urmărește o dezvoltare durabilă și performantă a sectorului agroalimentar, securitatea alimentară, precum și o nutriție îmbunătățită, bazată pe produse dintr-o agricultură sustenabilă. Eficienţa acestui sector are efecte importante pentru îmbunătățirea și creșterea calității vieții oamenilor, pentru asigurarea unui trai civilizat tuturor cetățenilor, precum și pentru încurajarea producției ecologice. Prin iniţiative educaționale specifice, domeniul educației fizice și sportului oferă suport în eradicarea malnutriției și în combaterea obezităţii, reprezentând, totodată, un model în ceea ce privește alimentația sănătoasă și securitatea alimentară prin alegerea, promovarea unor producători serioși și responsabili și prin abordarea problemei deșeurilor alimentare. Activităţile specifice acestui domeniu au puterea de a schimba comportamentele oamenilor, canalizându-le către un viitor durabil.

Sănătate şi bunăstare - garantarea unei vieți sănătoase, asigurarea și promovarea bunăstării oamenilor la orice vârstă

Obiectivul urmărește, în principal, scăderea ratei de mortalitate (în special, a celei infantile), reducerea incidenței bolilor de natură virală și infecțioasă, precum și a patologiilor cronice. De asemenea, obiectivul urmărește prevenirea consumului de droguri și a altor substanțe nocive și intervențiile terapeutice, precum și tratarea bolilor mintale. Practicarea activităţilor fizice și, astfel, adoptarea unui mod de viață activ au ca rezultat o stare de spirit pozitivă, creșterea încrederii în forțele proprii, reducerea nivelului stresului, factori importanți de care depind sănătatea și bunăstarea oamenilor. Educația fizică și sportul pot fi utilizate cu succes în domeniul sănătății și în adoptarea conceptului de viața sănătoasă și activă.

Educație de calitate - garantarea unei educaţii de calitate şi promovarea oportunităţilor de învăţare, de-a lungul vieţii pentru toţi

Acest obiectiv urmărește, în special, asigurarea accesului tuturor copiilor la un sistem educaţional de calitate, indiferent de posibilități materiale, de zonă geografică sau de etnie, și reducerea abandonului școlar. Mai mult, se dorește creșterea importantă a numărului de indivizi, atât tineri, cât și adulți, $\mathrm{cu}$ diferite competențe profesionale, necesare obținerii mai facile a unui loc de muncă decent sau dezvoltării unor activități antreprenoriale. $\mathrm{O}$ educație de calitate are ca rezultat dobândirea cunoştinţelor și competențelor necesare promovării unei dezvoltări durabile a societății. Educaţia fizică și sportul au un rol motivational puternic pentru copii și tineri, încurajându-i să participe la educația clasică, formală, cât și la cea informală, ajutându-i să-și îmbunătătească rezultatele la învățătură și să-şi crească performanța academică. Educaţia fizică și sportul au calitatea de a crea oportunități pentru învățare în afara școlii, ajutând la formarea și educarea unor abilități și valori cheie pentru viață, cum ar fi toleranţa, spiritul de sacrificiu, întrajutorarea și camaraderia.

Egalitate între sexe - realizarea egalităţii între sexe şi întărirea rolului femeii în societate

Scopurile acestui obiectiv sunt prevenirea și combaterea violenței îndreptate împotriva persoanelor de sex feminin, egalitatea de șanse și accesul neîngrădit al acestora la un loc de muncă și la ocuparea unor posturi de conducere în viaţa publică, economică și politică. Referitor la acest 
punct, educația fizică și sportul au un rol important în formarea și dobândirea de cunoștințe, deprinderi și abilități de către femei, stimulând progresul acestora în societatea contemporană, având ca rezultat eliminarea discriminării faţă de ele. De asemenea, prin intermediul activităților fizice și sportive, se promovează egalitatea între sexe.

Apă curată şi sanitaţie - asigurarea disponibilității şi managementului durabil al apei şi sanitaţiei, pentru toţi

Obiectivul urmărește creșterea nivelului de trai și a calității vieții prin asigurarea unor condiții sanitare și de igienă civilizate (servicii publice, rețele de apă și canalizare), în special pentru cei aflați în situații vulnerabile, respectarea standardelor internaționale privind gospodărirea apei potabile, reciclarea apelor uzate și a deșeurilor și, de asemenea, creșterea eficienței în procesul de utilizare a apei, încurajând reciclarea și reutilizarea în vederea reglementării problemei privind deficitul de apă. În cadrul activităților specifice domeniului educației fizice și sportului (înot, canotaj etc.), se pot promova acțiuni specifice privind îmbunătăţirea calității apei, reducerii deversărilor de substanțe poluante și reciclării apelor uzate. De asemenea, un prim pas care poate servi ca model în managementul apei îl reprezintă creșterea eficienței în utilizarea apei în complexele și dotările sportive.

Energie curată şi la prețuri accesibile asigurarea accesului tuturor la energie la preţuri accesibile, într-un mod sigur, durabil şi modern

Prin acest obiectiv, se urmărește creșterea confortuluișicalității vieții prin asigurarea accesului neîngrădit la surse energetice a tuturor indivizilor și comunităților. De asemenea, se are în vedere protejarea mediului prin transferul accentuat către surse alternative care folosesc energia regenerabilă și combustibili cu conținut scăzut de hidrocarburi. Domeniul educației fizice și sportului poate juca un rol important în atingerea obiectivelor privind folosirea energiei regenerabile, creșterea eficienței energetice și accesul la energie curată prin aplicarea și respectarea standardelor şi recomandărilor din domeniu. Prin intermediul activităților specifice, se pot iniţia acțiuni și campanii care să susțină asigurarea unui acces liber la energie, pentru toți oamenii și comunitățile.

Muncă decentă şi creştere economică promovarea unei creşteri economice susținute, deschise tuturor şi durabile, a ocupării depline şi productive a forței de muncă şi a unei munci decente pentru toți

Acest obiectiv urmărește: creșterea economică sustenabilă; crearea permanentă de noi locuri de muncă; antreprenoriatul; modernizarea tehnologică și inovarea; asigurarea unor condiţii de muncă decente pentru toți cetățenii, indiferent de vârstă; integrarea în câmpul muncii a persoanelor cu dizabilități; remunerarea echitabilă și accesul la diferite surse de finanţare. De asemenea, în cadrul acestui obiectiv se promovează diversitatea culturală, produsele cu specific zonal și local, respectul pentru datini și tradiţii, pentru mediul în care trăim. Valențele educației fizice și sportului pot juca un rol important în promovarea unei creșteri economice sustenabile și durabile prin eliminarea oricăror forme de discriminare și prin raportarea activității de producție și de ocupare a forței de muncă la standardele specifice de muncă, având ca rezultate crearea unor posibilități multiple de angajare și dezvoltarea unor abilități privind capacitatea de inserție profesională.

Industrie, inovaţie şi infrastructură construirea unor infrastructuri rezistente, promovarea industrializării durabile şi încurajarea inovaţiei

În cadrul acestui obiectiv, se urmărește dezvoltarea infrastructurii calitative și durabile, pentru a sprijini progresul economic și creșterea calității vieții tuturor oamenilor, modernizarea infrastructurii și rentabilizarea industriilor prin retehnologizare, bazată pe metode ecologice, dezvoltareacercetăriiștiințificeșimărireanumărului de angajați în acest domeniu, intensificarea colaborării statului cu mediul privat, încurajarea inovațiilor. Educația fizică și sportul pot stimula abordările înnoitoare ale industrializării și pot inspira constructiv procesele de cercetare și inovare. Contribuția activităților specifice sportului la acest obiectiv se poate materializa prin asigurarea unui acces echitabil la infrastructurile sportive și, de asemenea, prin sprijinul acordat pentru construirea de noi săli de sport și de baze sportive moderne.

Inegalități reduse - reducerea inegalităților în interiorul țărilor şi de la o țară la alta

Acest obiectiv urmărește reducerea decalajelor, eliminarea tuturor discriminărilor și iniţierea unor politici referitoare la realizarea progresivă a egalității între state și între oameni, în toate domeniile (fiscal, salarial, educațional și de 
protecție socială). Educația fizică și sportul dețin pârghiile necesare promovării de valori sociale ca: egalitate, toleranță, diversitate, integrare socială, indiferent de zonă geografică, vârstă, sex, rasă, etnie, origine, orientare sexuală, religie, nivel social, având posibilitatea de a rezolva cu succes eliminarea inegalităților și nedreptăților și în zone greu accesibile, integrând, astfel, și comunitățile umane.

Oraşe şi comunităţi durabile - dezvoltarea oraşelor şi aşezărilor umane, pentru a fi deschise tuturor, sigure, reziliente şi durabile

Obiectivul vizează asigurarea unor condiții necesare unei vieți demne pentru toți oamenii atât din mediul urban, cât și din cel rural, prin acces la servicii de bază și transport public eficient, toate la costuri accesibile, protecția și conservarea patrimoniului cultural și reducerea impactului negativ asupra mediului. Educația fizică și sportul pot servi la depăşirea obstacolelor și barierelor de orice fel din mediul ambiant, din transporturi sau servicii publice, asigurând accesul neîngrădit al tuturor la facilitățile sale și ajutându-i pe cei aflați în situații vulnerabile. De asemenea, utilizarea spațiilor publice specifice domeniului educație fizică și sport, ca săli de sport, stadioane etc., încurajează și facilitează interacțiunea oamenilor și socializarea.

Consum şi producție responsabile - asigurarea unor tipare de consum şi de productie durabile

Obiectivul urmărește transferul treptat către un model inovator de dezvoltare, caracterizat prin mărirea eficienței și productivității resurselor, printr-un bun management al deșeurilor și prin diminuarea fenomenului de risipă a alimentelor. Pentru realizarea acestor elemente, se are în vedere scăderea consumurilor, reciclarea și reutilizarea, precum și încurajarea firmelor și întreprinderilor să implementeze practici durabile în producție în domeniul achizițiilor publice. Toate acestea urmăresc creșterea gradului de conștientizare a populației asupra a ceea ce înseamnă și ce reprezintă un stil de viață dus în armonie cu mediul natural. Educația fizică și sportul pot juca un rol important în ceea ce privește acest nou model de dezvoltare, care susțin stiluri de viață prietenoase cu mediul înconjurător și cu resursele naturale prin organizarea și promovarea unor campanii de educare și conștientizare a oamenilor și prin promovarea serviciilor şi industriilor benefice acestei noi orientări.
Acțiuni de stabilizare climatică - adoptarea unor măsuri urgente de combatere a schimbărilor climatice şi a impactului lor

Obiectivul urmărește găsirea celor mai bune și viabile soluții pentru combaterea pericolelor și adaptarea la schimbările climatice din ultimii ani, pentru diminuarea consecințelor, în cazul unor dezastre naturale, și pentru creșterea nivelului de educație și conștientizare a populației privind aceste schimbări climatice și influența lor. Prin activități specifice, proiecte bazate pe sport și mesaje referitoare la schimbările climatice, domeniul educație fizică și sport poate contribui activ la campaniile privind combaterea efectelor datorate acestor modificări, creșterea gradului de conștientizare a populației asupra acestor fenomene, precum și încurajarea și sprijinirea revenirii la normal și a reconstrucției facilităţilor din comunitătile afectate de dezastre.

Viața acvatică - conservarea şi utilizarea durabilă a oceanelor, mărilor şi resurselor marine pentru o dezvoltare durabilă

Principalele direcții de acțiune ale acestui obiectiv vizează: prevenirea și reducerea efectelor contaminării și poluării mediului marin; protecția și conservarea ecosistemelor marine și a zonelor de coastă și asigurarea condițiilor pentru un pescuit durabil. În acest sens, educația fizică și sportul își aduc contribuția și în acest sector de activitate prin acțiunile și evenimentele sportive organizate, în special prin cele din domeniul sporturilor acvatice, promovându-se protecția, conservarea și utilizarea pe termen lung, în mod echilibrat, a mărilor și oceanelor.

Viața terestră - protejarea, restabilirea şi promovarea utilizării durabile a ecosistemelor terestre, gestionarea durabilă a pădurilor, combaterea deșertificării, stoparea degradării solului şi refacerea acestuia și oprirea pierderilor de biodiversitate

În cadrul acestui obiectiv, se urmărește: protejarea, conservarea, utilizarea și gestionarea durabilă a ecosistemelor terestre și montane; stoparea defrișărilor ilegale și necontrolate a pădurilor; combaterea fenomenului de deșertificare; refacerea și reintroducerea în circuitul agricol a terenurilor cu soluri degradate, afectate de secetă, inundații și deșertificare; dezvoltarea infrastructurii verzi; protejarea și conservarea zonelor umede și susținerea cercetării în domeniu. Educația fizică 
și sportul pot contribui și pot susține conservarea, protejarea și folosința durabilă a ecosistemelor tot prin acțiuni, activități și mesaje cu caracter sugestiv, care încurajează practicile și măsurile de protecție și care urmăresc conștientizarea populației în privința respectului față de un mediu înconjurător ecologic.

Pace, justiție şi instituții eficiente - promovarea unor societăți pașnice și incluzive pentru o dezvoltare durabilă, a accesului la justiţie pentru toate categoriile sociale şi crearea unor instituții eficiente, responsabile şi incluzive la toate nivelurile

Acest obiectiv urmărește: dezvoltarea capitalului social; promovarea păcii, toleranței și înțelegerii dintre oameni; cultivarea nonviolenței pe toate planurile; eradicarea corupției; dezvoltarea și modernizarea instituțiilor statului; creșterea nivelului de reprezentare a cetățenilor la toate nivelurile procesului decizional; protejarea intereselor și respectarea libertăților fundamentale ale omului și asigurarea unui acces liber și neîngrădit la informații. Educația fizică și sportul, prin valorile lor fundamentale, ca fairplay, ca respect față de adversar, ca spirit de întrajutorare și muncă în echipă, reprezintă un puternic canal de comunicare, transmitere și diseminare a mesajelor de unitate și reconciliere și oferă un cadru favorabil pentru promovarea păcii, înţelegerii și dialogului dintre oameni și state. De asemenea, prin entităţile și instituțiile sale, militează pentru o politică corectă, o guvernare eficientă și promovează respectarea drepturilor fundamentale ale omului.

Parteneriate pentru realizarea obiectivelor - consolidarea mijloacelor de implementare și revitalizarea parteneriatului global pentru dezvoltare durabilă

Acest ultim obiectiv al Agendei 2030 ONU pentru dezvoltare durabilă urmărește respectarea de către toți actorii implicați a angajamentelor internaţionale asumate privind dezvoltarea durabilă, identificarea, în dezbaterile din cadrul ONU, UE și al altor instituții internaționale, a unor soluții viabile și realiste pentru sprijinirea țărilor în curs de dezvoltare, stimularea investițiilor și altor iniţiative, activităţi economice și proiecte de voluntariat care promovează principii, metode și practici favorabile dezvoltării sustenabile a țărilor în curs de dezvoltare.

Domeniul educaţie fizică și sport deține resurse nebănuite, care, puse în mișcare, sunt capabile să aducă oamenii împreună, să genereze sinergii, să creeze rețele și să realizeze parteneriate cu entităţi dintr-o multitudine de sectoare diferite, dar interesate și angrenate în lupta pentru pace și dezvoltare durabilă.

Având în vedere obiectivele Agendei 2030 ca proiecție pentru dezvoltarea societății, personal, pot consolida imaginea domeniului educaţie fizică şi sport şi a implicării acestuia într-o dezvoltare durabilă, indicând câteva exemple concrete în acest sens:

- evenimentele sportive organizate de Asociatia Invictus Team România, în care voluntarii, militari și civili susțin diverse cauze de tip caritabil (Jocurile Paralimpice Invictus, Duatlonul Regal, Ștafeta Veteranilor etc.);

- evenimentele caritabile organizate de „Fundația Roger Federer”, denumite „The Match in Africa", la care participă, alături de R. Federer, diferite personalități marcante ale vieții publice, ca Bill Gates, Rafael Nadal, Andy Murray, Trevor Noah etc., ocazie în care se strâng fonduriimportante pentru realizarea unor proiecte de solidaritate pe continentul african (în 2017, la meciul organizat la Seattle, s-au strâns în jur de 2.000.000 de dolari);

- Swimathon, unul dintre cele mai mari evenimente sportive caritabile din România, organizat cu scopul declarat de a strânge fonduri pentru a asigura un acces mai facil al copiilor, din zonele rurale defavorizate, cu boli cronice grave la servicii medicale gratuite și pentru implementarea unui serviciu pilot de tratare și monitorizarea pacientului la domiciliu;

- semimaratonul Gerar, un eveniment sportiv de tradiţie printre alergătorii din România, organizat de Clubul Sportiv RO CLUB MARATON şi de asociaţia People for Sport România, în parteneriat cu Universitatea Politehnica Bucureşti şi cu Asociaţia Bucharest Running Club, având ca obiective declarate reducerea deșeurilor, protejarea mediului înconjurător și susținerea comunității.

În concluzie, Agenda 2030 pentru dezvoltare durabilă este o strategie extrem de ambiţioasă și de importantă pentru viitorul planetei și pentru progresul și creșterea calității vieții locuitorilor acesteia. Toate cele 17 obiective de dezvoltare durabilă sunt universal aplicabile, sunt conectate între ele, au un caracter mondial, în realizarea acestora toate țările, indiferent de nivelul de dezvoltare actual, având o responsabilitate 
comună. Prin urmare, ONU și statele membre sunt focusate permanent pe identificarea de soluții și de metode de realizare a acestor obiective și, aşa după cum am prezentat anterior, utilizarea valențelor și resurselor caracteristice domeniului educației fizice și sportului reprezintă una dintre căile viabile de înfăptuire a acestora.

În opinia mea, susținerea sistemului de educație fizică și sport și implicarea tuturor factorilor de decizie în folosirea acestui domeniu ar aduce plusvaloare întregii societăți românești pe termen mediu şi lung. Prezentul articolul poate avea ca efecte creșterea gradului de cunoaștere a principalelor obiective ale Agendei 2030 a ONU atât de către cei care activează în domeniu, cât și de către publicul larg, o planificare a viitoarelor activităti sportive, având în vedere aceste obiective, acordarea importanței cuvenite educației fizice și sportului de către toți specialiștii din toate domeniile sociale, precum și valorificarea resurselor acestui domeniu pentru a contribui la o dezvoltare durabilă a societății.

\section{NOTE:}

1 *** Report of the World Commission on Environment and Development: Our Common Future, http://www.eytv4scf. net/wced -ocf.htm, accesat la 24.10.2020.

2 *** Strategia națională pentru dezvoltarea durabilă a României 2030, București, 2018, p. 15.

3 https://www.un.org/sport/sites/www.un.org.sport/ files/ckfiles/files/SportforSDGsfinalversion9.pdf, accesat la 20.06.2019.

4 https://www.mae.ro/node/35919, accesat la 15.10.2020.

\section{BIBLIOGRAFIE}

*** Strategia naţională de apărare a ţării pentru perioada 2020-2024, București, 2020.
*** Strategia naţională pentru dezvoltarea durabilă a României 2030, București, 2018.

*** Report of the World Commission on Environment and Development: Our Common Future, http://www.eytv4scf.net/wced -ocf.htm

*** Transforming our world: the 2030 Agenda for Sustainable Development, https:// sustainabledevelopment.un.org/post2015/transfor mingourworld

*** The 2030 Agenda for Sustainable Development and the SDGs, https://ec.europa. $\mathrm{eu} /$ environment/sustainable-development/SDGs/ index_en.htm

*** UNESCO and Sustainable Development Goals, https://en.unesco.org/sustainabledevelopm ent goals

Popa M., Orientări şi tendințe în sportul universitar românesc, Editura Presa Universitară Clujeană, Cluj-Napoca, 2018.

https://www.un.org/sport/sites/www.un.org. sport/files/ckfiles/files/SportforSDGsfinalversion9. pdf

https://www.mae.ro/node/35919

http://dezvoltaredurabila.gov.ro/web/dd-ro/

https://www.eurosport.ro/tenis/federer-sinadal-se-pregatesc-de-un-meci-demonstrativspecial-alaturi-de-bill-gates-si-trevor-noah_sto7 652526/story.shtml

https://gerar.ro/despre/eveniment-responsabil/

https://www.prosport.ro/alte-sporturi/swimath on-cel-mai-mare-eveniment-sportiv-caritabil-dinromania-se-desfasoara-in-perioada-27-28-iunie19044429

https://www.facebook.com/events/curtea-dearges/duatlonul-regal-invictus-editia-a-iii-a/217 0465683244322/ 